\title{
Experimental Search for New Means of Pathogenetic Therapy COVID-19: Inhibitor of H2-Receptors Famotidine Increases the Effect of Oseltamivir on Survival and Immune Status of Mice Infected by A/PR/8/34 (H1N1)
}

\author{
N. V. Goncharov ${ }^{a, b, *}$, K. A. Vasilyev ${ }^{c}$, I. V. Kudryavtsev ${ }^{d}$, P. P. Avdonin ${ }^{e}$, D. A. Belinskaia ${ }^{a}$, \\ M. A. Stukova ${ }^{c}$, O. V. Shamova ${ }^{d}$, and P. V. Avdonin ${ }^{e}$ \\ ${ }^{a}$ Sechenov Institute of Evolutionary Physiology and Biochemistry, Russian Academy of Sciences, \\ St. Petersburg, Russia \\ ${ }^{b}$ Research Institute of Hygiene, Occupational Pathology and Human Ecology, p/o Kuzmolovsky, \\ Vsevolozhsky District, Leningrad Region, Russia \\ ${ }^{c}$ Smorodintsev Research Institute of Influenza of the Ministry of Health of the Russian Federation, \\ St. Petersburg, Russia \\ ${ }^{d}$ Institute of Experimental Medicine, St. Petersburg, Russia \\ ${ }^{e}$ Koltsov Institute of Development Biology, Russian Academy of Sciences, Moscow, Russia \\ *e-mail: ngoncharov@gmail.com
}

Received December 14, 2021

Revised December 23, 2021

Accepted December 23, 2021

\begin{abstract}
The development of drugs for the therapy of COVID-19 is one of the main problems of modern physiology, biochemistry and pharmacology. Taking into account the available information on the participation of mast cells and the role of histamine in the pathogenesis of COVID-19, as well as information on the positive role of famotidine in the prevention and treatment of coronavirus infection, an experiment was carried out using famotidine in a mouse model. We used a type A/PR/8/34 (H1N1) virus adapted to mice. The antiviral drug oseltamivir (Tamiflu), which belongs to the group of neuraminidase inhibitors, was used as a reference drug. The use of famotidine in combination with oseltamivir can increase survival, improve the dynamics of animal weight, reduce the level of NKT cells and increase the level of naive T-helpers. Further studies of famotidine in vivo should be aimed at optimizing the regimen of drug use at a higher viral load, as well as with a longer use of famotidine.
\end{abstract}

DOI: $10.1134 / \mathrm{S} 0022093022010203$

Keywords: virus, mice, famotidine, H2-receptors, cellular immunity, acute respiratory distress syndrome, COVID-19 


\begin{abstract}
Abbreviations: ACE2 - angiotensin converting enzyme 2; APTT-activated partial thromboplastin time; ARDS - acute respiratory distress syndrome; AT1-angiotensin II receptor type 1; COVID-19coronavirus disease 2019; COX-2-cyclooxygenase-2; CRP-C-reactive protein; CT-computed tomography; DIC-disseminated intravascular coagulation; EC-endothelial cells; DCE-developing chicken embryos; ELA - endogenous lipid autacoids; FS-forward scattering; GM-CSF-granulocyte-macrophage colony-stimulating factor; GPCR-G protein-coupled receptors; IL-1/6/8interleukin-1/6/8; MAS-G protein-coupled receptor that binds angiotensin (1-7), a metabolite of angiotensin II; MCAS - mast cell activation syndrome; MCP-1-monocyte chemoattractant protein 1; NET - neutrophil extracellular traps; NK-natural killers; NKT cells-Natural killer T cell; NRP - neuropilin; NSAID - non-steroidal anti-inflammatory drugs; PAF-platelet-activating factor; PEEP-positive end-expiratory pressure; PGE-prostaglandin E; ROS-reactive oxygen species; SARS-CoV-2-severe acute respiratory syndrome coronavirus 2; SS—-side scattering; TMPRSS2type II transmembrane-bound serine protease; TNF- $\alpha$ - tumor necrosis factor alpha; vWF-von Willebrand factor
\end{abstract}

The coronavirus pandemic has spurred research of the role of endothelial cells (EC) in the pathogenesis of COVID-19. EC damage caused by SARS-CoV-2 exacerbates endothelial dysfunction that commonly occurs with aging, hypertension, and obesity. A sharp increase in endothelial dysfunction as a result of damage by SARS-CoV-2 causes the development of acute respiratory distress syndrome (ARDS). One of the main problems in studying the pathogenetic mechanisms of the development of COVID-19 is the molecular biological characteristics of EC in different organs and within one organ (primarily in the lungs, but also in the kidneys, heart and brain), since the virus penetrates into different cells with varying degrees of probability and causes consequences of different nature and intensity of manifestation [1]. In this case, the main pathogenetic consequence, which largely determines the outcome of the disease, is hypercoagulation of blood as a result of massive release of von Willebrand factor (vWF) by EC [2, 3]. Angiotensin converting enzyme 2 (ACE2) is the main glycoprotein used by SARSCoV-2 to enter cells. The penetration of the virus into cells is associated with a decrease in the number of expressed ACE2 molecules, with subsequent disruption of the functional balance of the functional axes ACE/AngII/AT1 and ACE2/ Ang(1-7)/Mas [4]. Other coronavirus "receptors" on EC have also been determined, such as CD209L (L-SIGN), CD209 (DC-SIGN) [5], neuropilin receptors (NRP) [6] and CD147/basigin [7]. CD209L is especially strongly expressed in epithelial and endothelial cells of the lungs and kidneys, mediating the entry of SARS-CoV-2 into cells [5]. It is also well known that penetration of SARS-CoV-2 into cells requires proteolytic activation of the spike protein, which involves TMPRSS2 peptidases, furin, and cathepsins [1].

According to some scientists, there are two main pathogenetic factors that cause alveolar edema in COVID-19: infection of cells with virus SARS-CoV-2 and degranulation of mast cells with the release of many compounds that can affect the function of cell and basement membranes, glycocalyx and the integrity of tight junctions [8]. Among these compounds, histamine, bradykinin, heparin, tryptase, and cytokines are of the greatest interest from the point of view of the pathogenesis of COVID-19. In the outpatient setting, early COVID-19 is usually indistinguishable from other "flu-like" illnesses with symptoms ranging from sore throat, headache and diarrhea to fever, cough and myalgia. However, in these first few days, COVID-19 can be associated with anosmia [9]. Severe forms of COVID-19 are characterized not only by pneumonia and ARDS, but also by the development of systemic multiple organ failure, as a result of an uncontrolled "cytokine storm", including the release of pro-inflammatory cytokines (such as TNF- $\alpha$, IL-6, IL-1, IL-8 and MCP-1) [10]. However, this storm is not the only, predetermined and irreversible event. First, SARS-CoV-2 causes massive cell death with the formation of cellular debris, which activates inflammasomes not only in innate immune cells, but also in EC, triggering the socalled "eicosanoid storm". Eicosanoid storm is a surge in the proinflammatory bioactive lipid mediators (such as prostaglandins and leukot- 
rienes) that fuel local inflammation $[11,12]$. Secondly, there has been a recent paradigm shift in the concept of inflammation, which consists in the fact that in the process of inflammation itself there is a mechanism for its cessation thanks to specialized endogenous lipid autacoids (ELA) resolvins, lipoxins and protectins, which perform not so much anti-inflammatory but restrictive functions. ELA promote removal of cellular debris by macrophages and counteracts excessive release of proinflammatory cytokines/chemokines [13]. It is believed that the disorder in the mechanism of limiting and stopping inflammation plays a decisive role in maintaining pathological inflammation in COVID-19 and other viral infections [14]. The disorder can be caused by common anti-inflammatory agents such as nonsteroidal anti-inflammatory drugs (NSAID) and cyclooxygenase- 2 inhibitors (COX-2, COX-2), as they indiscriminately inhibit the eicosanoid pathways that produce these "control mediators" and thereby impede the process of active limitation of inflammation [13, 14].

The role of EC and reactive oxygen species (ROS) in the generation of these lipid autacoids has not been studied.

The action of histamine is mediated by four types of receptors- $\mathrm{H} 1, \mathrm{H} 2, \mathrm{H} 3$ and $\mathrm{H} 4$. The most well-known functions of $\mathrm{H} 1$-receptors are the regulation of vasodilatation and bronchoconstriction, since the receptors of this type are localized mainly on endothelial and smooth muscle cells of blood vessels. H2-receptors are mainly involved in modulating gastric secretion of parietal cells [15]. In sepsis, histamine, through the activation of $\mathrm{H} 1$ - and $\mathrm{H} 2$-receptors, contributes to the development of target organ failure. The use of $\mathrm{H} 1-$ and $\mathrm{H} 2$-receptor antagonists has shown that $\mathrm{H} 1$ - and H2-receptors are involved in septic damage to the lungs and liver, but only H2-receptors contribute to septic kidney damage [16].

Most of the current reviews explain the clinical and pathogenetic knowledge of COVID-19 based on standard models of antiviral innate and adaptive immune response that do not consider the role of histamine and mast cells as its primary source. The existing schemes describe the cellular response associated with inflammation and the participation of monocytes, macrophages, adap- tive $\mathrm{T}$ and $\mathrm{B}$ cells $[17,18]$. This type of immune response is also used to explain the pulmonary intravascular coagulopathy associated with COVID-19 [19]. We are supporters of an alternative paradigm, according to which the activation of mast cells caused by infection with SARSCoV-2, the release of histamine and pro-inflammatory cytokines (mainly $\mathrm{TNF}-\alpha$ ) from mast cells is the most important link in the pathological cascade and is responsible for most of the atypical symptoms associated with COVID-19 [8, 20, 21]. This model is consistent with histopathological data and is supported by clinical and pharmacological data suggesting potential benefits of histamine H2-receptor blockade with famotidine. This model is also supported by a significant overlap between the clinical signs of the initial phase of COVID-19 and mast cell activation syndrome (MCAS) [22-24], similarities with the clinical signs of Dengue hemorrhagic fever and shock syndrome (including T-lymphocyte depletion) in the later stages of COVID-19 [25, 26]. In addition, the consequences of COVID-19 such as stroke and cardiovascular disease correspond to Kounis syndrome [27], as evidenced by the data on an increased number of mast cells in the walls of the alveolar septa and lung parenchyma infected with SARS-CoV-2 [28].

The aim of this work is to theoretically substantiate and experimentally verify the effectiveness of the H2-receptor inhibitor famotidine as a potential component of the complex for the pathogenetic therapy of COVID-19. In the experimental search for new means of pathogenetic therapy for coronavirus infection, it is important to understand that mice are only carriers of coronavirus infection. However, this problem is solved by using other strains of influenza that cause a similar condition in mice, in particular the development of immune imbalance, cytokine storm and ARDS in the terminal stage of the disease, which is the direct cause of death. One of the viral strains causing this disease in mice is $\mathrm{A} / \mathrm{PR} / 8 / 34$ (H1N1) [29].

\section{MATERIALS AND METHODS}

Experiments with animals were carried out in accordance with the European Convention for 
the Protection of Vertebrate Animals used for Experimental and Other Scientific Purposes (Strasbourg, 1986), Order of the Ministry of Health and Social Development of the Russian Federation of August 23, 2010 No. 708n "On Approval of the Rules of Laboratory Practice".

Outbred female mice weighing 19-23 g were purchased from the Rappolovo nursery (Leningrad region). In the work we used the virus type A/PR/8/34 (H1N1) adapted to mice. The virus was accumulated in the allantoic cavity of 10-dayold developing chicken embryos (DCE) at $34^{\circ} \mathrm{C}$ for $48 \mathrm{~h}$, aliquots were prepared and stored at $-70^{\circ} \mathrm{C}$. Mice were challenged intranasally under light ether anesthesia. Animals were injected with $30 \mu \mathrm{L}$ of allantoic fluid containing an infective dose of 5lg[TCID50] influenza A/PR/8/34 (H1N1) virus. Work with objects was carried out in accordance with the sanitary and epidemiological rules SP 1.3.2322-08 "Safety of working with microorganisms of III-IV groups of pathogenicity (danger) and pathogens of parasitic diseases" (entered into force on May 1, 2008, as amended on June 29, 2011).

Of 45 mice, 5 groups were formed: (1) negative control (intact animals), administration of saline, $n=5$; (2) positive control, infection and administration of saline intragastrically (i.v.), $n=10$; (3) infection and intravenous administration of oseltamivir, $n=10$; (4) infection and administration of famotidine intravenously, $n=10$; (5) infection and administration of oseltamivir with famotidine intravenously, $n=10$.

$20 \mathrm{mg}$ of famotidine were diluted in $2 \mathrm{~mL}$ of a mixture of DMSO + propylene glycol, the stock solution of $10 \mathrm{mg} / \mathrm{mL}$ was stored in the refrigerator. Working solutions for intragastric administration were prepared extempore: $100 \mu \mathrm{L}$ of the stock solution was diluted in $2.4 \mathrm{~mL}$ of saline or oseltamivir solution, each mouse was injected through a tube with a volume of $100 \mu \mathrm{L}$ per $10 \mathrm{~g}$, which corresponds to a dose of famotidine $4 \mathrm{mg} / \mathrm{kg}$. Drug administration was started on the day of infection ( 2 hours before) and continued for the next 4 days. The duration of the experiment was 14 days. A more detailed description of a similar model is given in [30].

Blood sampling for analysis was carried out on the 4th day after infection. Blood was taken from the cheek using a scarifier, as described in [31].

\section{Peripheral blood lymphocytes immunophenotyping}

In brief, $50 \mu \mathrm{L}$ of rat whole peripheral blood were stained on surface expression with the following specific fluorochrome-conjugated monoclonal antibodies: anti-rat CD44-FITC (cat. No. 103022, clone IM7, Biolegend Inc., USA), antirat CD49b-PE (cat. No. 108908, clone DX5, Biolegend Inc., USA), anti-rat CD8a-PerCP-Cy5.5 (cat. No. 100734, clone 53-6.7, Biolegend Inc., USA), anti-rat CD4-PE-Cy7 (cat. No. 116016, clone RM4-4, Biolegend Inc., USA), anti-rat CD3-APC (cat. No. 100236, clone 17A2, Biolegend Inc., USA), anti-rat CD45-APC-Cy7 (cat. No. 103116, clone 30-F11, Biolegend Inc., USA), anti-rat CD19-Brilliant Violet $421^{\mathrm{TM}}$ (cat. No. 115538, clone 6D5, Biolegend Inc., USA) and anti-rat CD62L-510 ${ }^{\mathrm{TM}}$ (cat. No. 104441, clone MEL-14, Biolegend Inc., USA). After incubation at room temperature in the dark for $15 \mathrm{~min}$, erythrocytes were lysed for $15 \mathrm{~min}$ with $0.25 \mathrm{~mL}$ of OptiLyse C Solution (Beckman Coulter, Inc., USA). Next, $0.25 \mathrm{~mL}$ of sterile PBS were added to each samples, after incubation at room temperature in the dark for $15 \mathrm{~min}$ lymphocyte cell suspensions were washed (7 min $330 \mathrm{~g}$ ) twice with a buffer (sterile phosphate-buffered saline (PBS) containing $2 \%$ of heat inactivated fetal bovine serum, Sigma-Aldrich, USA) and were resuspended in $0.5 \mathrm{~mL}$ of the PBS containing $2 \%$ of neutral buffered formalin solution (Sigma-Aldrich, USA). Sample acquisition was performed using a CytoFlex cytometer (Beckman Coulter, Inc., USA), equipped with 405, 488 and $638 \mathrm{~nm}$ lasers. At least 20000 lymphocytes were analyzed in each sample (doublets were excluded from the analysis using FS-area versus FS-weight dot plot). Obtained data were analyzed with Kaluza software (Beckman Coulter, Inc., USA). The data obtained were expressed as a percentage of the population of cells of interest.

\section{RESULTS}

Figure 1 shows data on survival (left) and body weight dynamics (right) in mice infected with influenza A/PR/8/34 and treated with oseltamivir, famotidine, and their combination. Kaplan- 

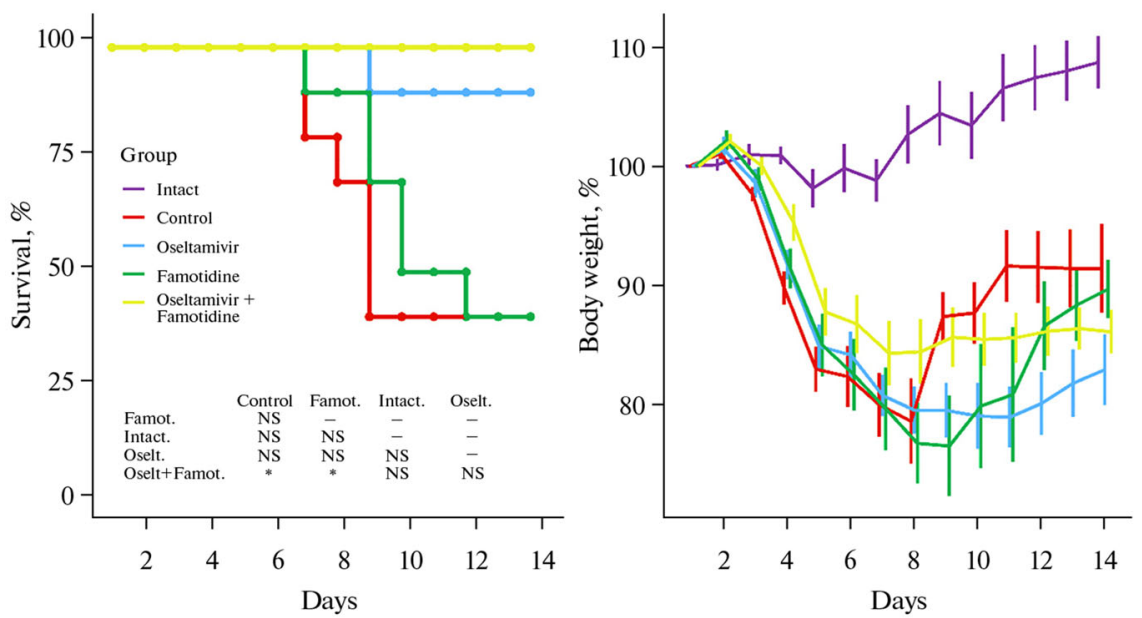

Fig. 1. Survival (left) and body weight dynamics (wright) in mice infected with A/PR/8/34 influenza virus and treated with oseltamivir, famotidine and a combination of both drugs. The Kaplan-Meier curves represent the percentage of survived animals at different time points after the challenge. Curves were compared using Log-Rank test. P-values are presented on the graph. On the body weight dynamics plot Means and Standard deviations are shown for each time point.

Meier curves represent the percentage of animals that survived at various time points after infection. The first death of animals was recorded on the 7 th day after infection in the $(+)$ control $(2$ out of 10 mice) and Famotidine (1 out of 10) groups. During 14 days of the experiment, 6 animals died in each of these two groups, which corresponds to a survival rate of $40 \%$. After 9 days, death of one mouse from the oseltamivir group was registered, after which not a single death occurred in this group of animals, which corresponds to a survival rate of $90 \%$. In the group of animals that received a mixture of famotidine and oseltamivir, no deaths were registered for 14 days, which corresponds to $100 \%$ survival. Animals of this group showed the best dynamics of body weight (minimal decrease) and outwardly looked better than animals of other experimental groups.

Multicolor flow cytometry was used to identify the main subpopulations of lymphocytes. T-lymphocytes were isolated based on the presence of CD3 on the cell surface, after which the total pool of $\mathrm{T}$-cells was divided into $\mathrm{T}$-helpers with CD3+CD4+ phenotype, cytotoxic T-lymphocytes with CD3+CD8+ phenotype, and NKT-cells with CD3+CD49b+ phenotype. Additionally, populations of B-lymphocytes (CD19+ cells) and natural killer cells $(\mathrm{CD} 3-\mathrm{CD} 49 \mathrm{~b}+)$ were isolated within the general pool of lymphocytes. The results of the analysis of the relative content of these types of lymphocytes are shown in Fig. 2. Thus, there were differences in the content of NKT-cells between the groups of intact animals and animals receiving both drugs (14.4 \pm 4.6 versus $9.1 \pm 3.0$ at $p=0.012$, respectively).

It is known that after activation, NKT-cells are capable of producing large amounts of interferon gamma, IL-4 and granulocyte-macrophage colonystimulating factor (GM-CSF), as well as many other cytokines and chemokines (IL-2, IL-13, IL-17, IL-21 and TNF-alpha). NKT-cells provide support and assistance to B cells [32]. At the same time, there is eosinophil-mediated inflammation in the lungs of COVID-19 patients, as well as an increased NKT cell response associated with ARDS and pneumonia [33].

In the course of further studies, T-helpers and cytotoxic $\mathrm{T}$-lymphocytes were divided into four main subpopulations of cells: "naive" CD44 ${ }^{\text {low-to-dim }} \mathrm{CD}^{2} \mathrm{~L}^{+}$cells, central memory (CM) cells with the $\mathrm{CD} 44{ }^{\text {hi }} \mathrm{CD} 62 \mathrm{~L}^{+}$phenotype, effector memory (EM) cells CD44hiCD62 $\mathrm{L}^{-}$and differentiated effector cells CD44 ${ }^{\text {low-to-dim }} \mathrm{CD} 62 \mathrm{~L}^{-}$. The results are presented in Fig. 3. It was shown that the combined use of oseltamivir and famotidine is accompanied by an increase of "naive" $\mathrm{T}$-helper cells in the circulation, which are capable of recognizing a wide range of invading pathogens, relative to the values obtained for animals receiving only famotidine $(72 \pm 6.4$ versus $61.4 \pm 10$ at $p=$ 
(a)

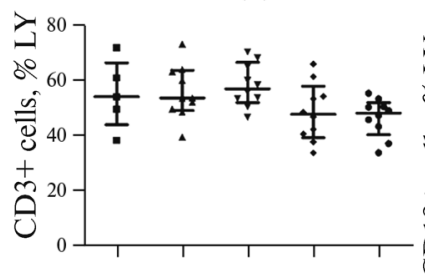

(d) (b)

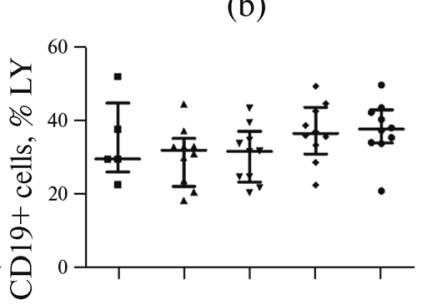

(e)

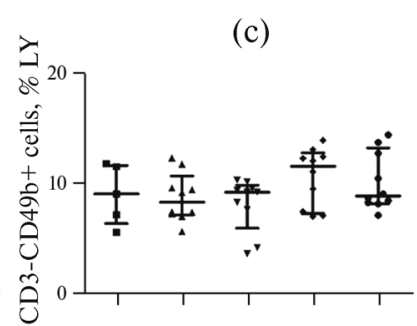

(f)
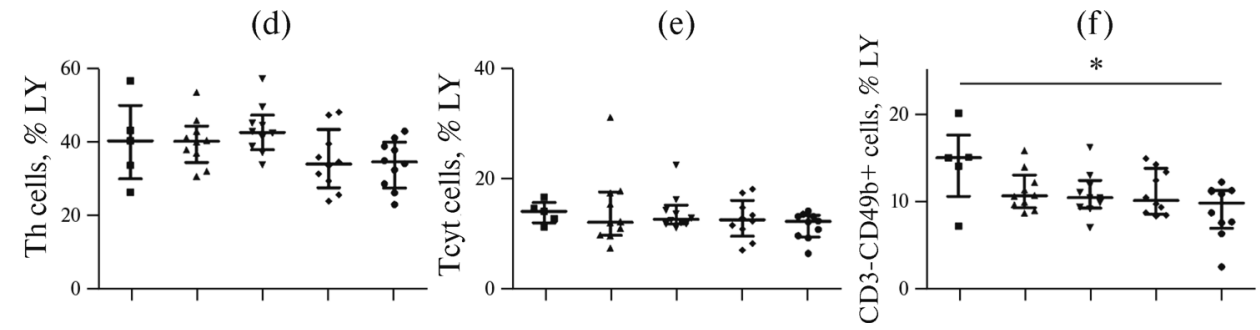

Fig. 2. Analysis of the relative content of the main subpopulations of peripheral blood lymphocytes. Here and below in Fig. 3: squares-intact animals $(n=5)$; triangles_animals of the control group $(n=10)$; inverted triangles-group of animals treated with oseltamivir $(n=10)$; diamonds-a group of animals that received famotidine $(n=10)$; circles-a group of animals treated with oseltamivir and famotidine $(n=10)$. Results are shown as median and interquartile range Med (Q25; Q75). Differences between groups were significant according to analysis of variance (ANOVA) and Tukey's test. ${ }^{*} p<0.05$.

(a)

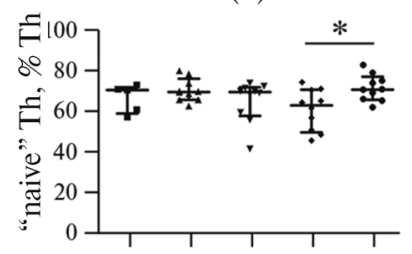

(e) (b)

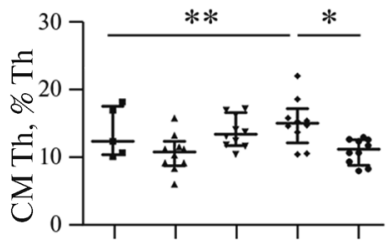

(f) (c)

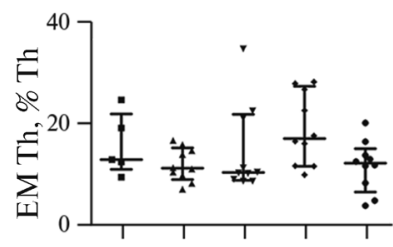

(g) (d)

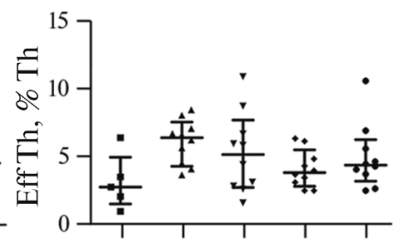

(h)
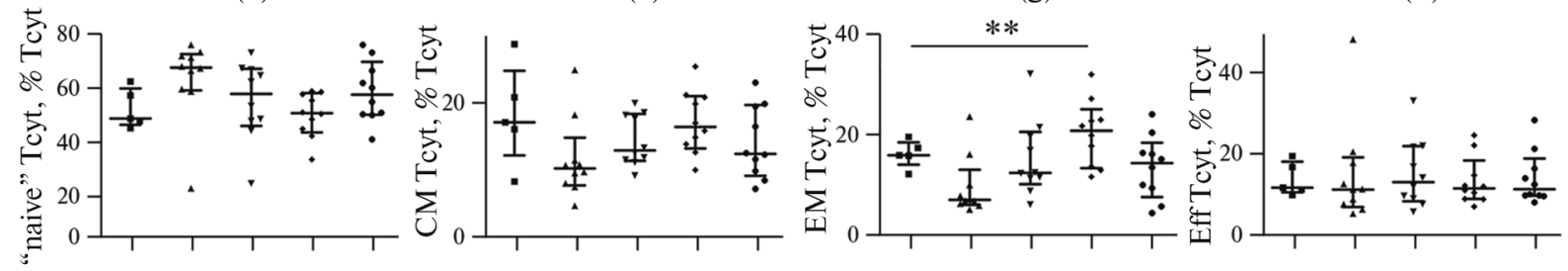

Fig. 3. Analysis of the relative content of the main subpopulations of T-helpers and cytotoxic T-lymphocytes of peripheral blood. ${ }^{*} p<0.05, * * p<0.01$.

0.040, respectively). In addition, in animals treated with famotidine, the proportion of $\mathrm{T}$-helpers of central memory increased relative to control animals and animals from the oseltamivir + famotidine group $(15.3 \pm 3.4$ versus $10.8 \pm 2.7$ and $11.1 \pm 1.8$ at $p=0.004$ and $p=0.012$, respectively). Moreover, when analyzing the subpopulation composition of cytotoxic T-lymphocytes, we also noted significant differences in the content of EM cells between the control group and the group of animals receiving famotidine $(16.2 \pm 2.6$ versus

\section{$20.2 \pm 6.4$ at $p=0.004$, respectively).}

In severe cases of COVID-19, there is a decrease in lymphocyte count, but an increase in white blood cell count and neutrophil-to-lymphocyte ratio (NLR). In especially severe cases, an increased level of inflammatory cytokines is associated with a significant decrease in the number of T-lymphocytes, especially T-helpers [34]. Another study found that, in severe cases of COVID-19, the cellular response is characterized by lymphocytopenia with a low content of naive 
T helper cells, along with CD8+ T cells and natural killer cells [35]. It is important to note that CD8+ and NK cells in surviving patients recovered after 8-14 days, while naive Th cells did not recover.

\section{DISCUSSION}

The pathophysiological effect of SARS-CoV-2 depends on a number of epigenetic factors (lifestyle, diet, smoking, etc.) that affect the balance of the activity of the functional axes ACE/AngII/ AT1 (vasoconstriction, ROS generation, inflammation) and ACE2/Ang(1-7)/Mas (vasodilation, antioxidant and anti-inflammatory effects) [36]. SARS-CoV-2, in comparison with SARS-CoV, is more contagious, but less virulent [37], which is associated with the different tropism of the viruses to different receptors, the spectrum and expression of the receptors in different organs and tissues [5]. Activation of AT1 receptors by angiotensin-II determines the generation of ROS in endothelial cells and vascular smooth muscle cells, as well as in the paraventricular nuclei of the hypothalamus [38]. The activity of ACE is associated not only with the formation of angiotensinII: a relationship has been found between the activity of this enzyme and the degree of mobilization of innate cellular immunity during tumor growth and infection, as well as the degree of expression of the proteins of the main histocompatibility complex class I and II [39].

The available scanty data on pathological changes in tissues in the early stages of COVID-19 support the assumptions about the combined effect of viral infection and the effects of histamine in the lungs. Thus, two different disease patterns are identified when examining lung tissue removed from a cancer patient at an early stage of COVID-19 [40]. In some lung tissue samples, there is a common mononuclear inflammatory pattern of interstitial pneumonitis with fibrinous exudate, which is caused by the viral infection. It should be noted that there are virtually no neutrophils or eosinophils in the inflammatory infiltrate. One of the explanations is that histamine activation of H2-receptors in neutrophils suppresses their effector functions, including generation of superoxide anion [41, 42], PAF-induced chemo- taxis [43], and biosynthesis of leukotrienes [44].

The functional activity of eosinophils is also suppressed upon activation of $\mathrm{H} 2$-receptors: the binding of histamine suppresses degranulation, decreasing the release of eosinophil peroxidase [45], and at higher concentrations inhibits the chemotaxis of eosinophils [46]. In other samples of lung tissue from patients with COVID-19, interstitial and alveolar edema occurs, while alveolar septa retain their normal architecture [47, 48]. This is an atypical picture observed with a viral infection, since there is no inflammation, and the fluid is a transudate. This is consistent with the concept of dysregulation of the fluid barrier due to the effect of histamine or other mast cell products on EC, pericytes, or type II pneumocytes. It is assumed that increased endothelial permeability is due to the activation of the H1-receptor by histamine, although no one has investigated the degree of expression of other types of histamine receptors on EC, smooth muscle cells or other ones. The presence of H2-receptors on mast cells is important: an increase in the intracellular level of cAMP, for example, with the help of forskolin, is used to inhibit the release of histamine from basophils and human mast cells [49]. Histamine can act as an autocrine regulator of mast cells in PGE2-dependent cytokine and TNF- $\alpha$ release; this autocrine feedback is mediated by H2- and H3-receptors [50]. Pulmonary edema associated with mast cell degranulation may correlate with the early phase of the so-called "quiet" or "happy" hypoxia [51]. In African green monkeys infected with SARSCoV-2, the number of mast cells in the lung parenchyma significantly increases, correlating with the severity of pneumonia [8]. These results are supported by autopsy data from a patient who died 5 days after the onset of symptoms of COVID-19: non-inflammatory transudative edema is clearly visible on micrographs [52]. In both cases, non-inflammatory pulmonary edema at an early stage of COVID-19 disease is accompanied by the release of histamine by mast cells [52]. Mast cell degranulation is correlated with the natural course of COVID-19, which goes through functionally and clinically different early and late phases. Most SARS-CoV-2 infections follow the typical early phase of any lower respiratory tract virus, in which most patients are asymp- 
tomatic or of minimal severity, and a minority develop ARDS at a later stage. Towards the end of the first week of symptom onset, COVID-19 patients develop shortness of breath. This occurs several days after cough and fever, which is not typical for other influenza viruses [53]. When examining patients with COVID-19 who have shortness of breath, oxygen saturation drops sharply during exercise. Computed tomography (CT) in such cases usually shows bilateral ground glass opacity, which indicates edema. Some authors attribute this to the loss of pulmonary vasoconstriction, one of the reasons for which may be the effect of histamine on $\mathrm{H} 2$-receptors of pericytes and/or on vascular smooth muscle cells. Additional causes may be edema due to the activation of H1-receptors, and microthrombosis of the pulmonary vessels. Such patients benefit from prone position, while positive end-expiratory pressure (PEEP) ventilation cannot help due to the lack of recruited alveoli [54]. At this stage, the patient is at greatest risk of developing serious complications, primarily ARDS with its 60-80\% mortality rate. In addition, patients may develop neurological symptoms and complications, including ischemic stroke [55-57]. Complications of the cardiovascular system in the later stages of COVID-19 disease include myocarditis, acute myocardial infarction, heart failure, arrhythmias, and venous thromboembolic events [58, 59].

The expression patterns of genes of the lung cells and of some blood cells give an idea of which cells can be infected and which of them are exposed to the action of histamine [60]. According to these data, epithelial cells (of airways, pneumocytes types 1 and 2) and vascular EC (including lymphatic cells) are more likely to be infected, based on the expression patterns of ACE2 and TMPRSS2 in these cell types. The cells with the highest expression of $\mathrm{H} 1$-receptors belong to the arterial endothelium. The expression of H1-receptors is significantly less on the endothelium of other vessels: pericytes, type 1 pneumocytes, vascular smooth muscle cells and myeloid granulocytes (including mast cells, neutrophils, and eosinophils), and is completely absent in venous vessels. The cells with the highest expression of $\mathrm{H} 2$-receptors are, first of all, type 1 pericytes, followed by smooth muscle cells, myeloid granulocytes and type 2 pericytes, type 2 pneumocytes, and only then vascular endothelium. Similar to H1-receptors, the expression of $\mathrm{H} 2$-receptors is also completely absent in venous vessels. We also should note the H4-receptors in the EC of the vessels (the maximum expression level is in the lymphatic cells), in type 1 pneumocytes, and in smooth muscle cells [60]. This data should be treated with great caution, since they were obtained on mouse embryos, and the dynamics of expression of these proteins or corresponding genes under the action of viruses, ROS, histamine and other pathogenetic factors or biologically active substances has not been studied.

Interaction with histamine and bradykinin receptors causes an increase in endothelial permeability through signaling pathways activating Akt1 kinase [61]. In addition, H2-receptor activates inositol metabolism through the Gq/11 proteins, which causes an increase in the concentration of $\mathrm{Ca}^{2+}$ in the cytosol and an increase in the permeability of the endothelial monolayer; this effect is reduced in the case of pretreatment of EC with famotidine [62, 63]. Histamine has a decisive effect on the state of EC of microvessels and blood-tissue barriers, especially in organs such as the lungs and the brain. The effect on histamine $\mathrm{H} 1$ - and $\mathrm{H} 2$-receptors leads to a decrease in the expression of claudin-1, which is the most important protein of tight junctions, and, as a consequence, to an increase in the permeability of the endothelial monolayer [64]. In addition to the functional response through action on histamine receptors, the ability of EC to metabolize histamine via monoamine oxidase (hydrogen peroxide is one of the products of this metabolism) is of great importance, along with the ability to capture histidine (capture can be enhanced by adding zinc sulfate) and to synthesize histamine using histidine decarboxylase [64]. In our studies, it was found that NADPH oxidase inhibitors suppress the excessive secretion of vWF by EC, induced by histamine [65]. It was previously shown that inhibition of ROS generation by type 2 NADPH oxidase (NOX2) reduces the intensity of inflammatory processes in the lungs when the body is affected by the virus of influenza A [66]. In numerous studies, hypercoagulability 
was noted in patients with COVID-19 and a new type of pulmonary coagulopathy was even identified, which manifests itself as microthrombosis of small vessels.

It was found that more than $50 \%$ of patients who died from COVID-19 had pulmonary microthrombosis [67]. This kind of thrombosis was detected not only in arterial vessels, but also in alveolar capillaries, in the absence of inflammation and ARDS [68]. Since small microthrombi are difficult to identify on CT, preliminary diagnosis is also difficult. Laboratory coagulation tests usually show normal or slightly increased prothrombin time and activated partial thromboplastin time, normal, increased or slightly decreased platelet count, but markedly increased levels of fibrinogen and especially D-dimers [69]. Some authors call this condition a variant of disseminated intravascular coagulation (DIC), but in fact, pulmonary microthrombosis in COVID-19 is not associated with bleeding, which is one of the signs of DIC, but rather resembles a hypercoagulable state. This coagulopathy appears to be a major component of the pathogenesis of COVID-19, since elevated D-dimer levels, along with elevated IL-6 and CRP levels, correlate with prognosis severity. However, in general, the mechanism of formation of pulmonary microthrombosis in COVID-19 remains unclear.

It is important to note that the level of $\mathrm{IgG}$ begins to rise within 4 days of the onset of symptoms of COVID-19, indicating secondary antigen exposure. The rapid rise in specific neutralizing antibodies beginning less than 7 days after exposure to SARS-CoV-2 indicates a secondary mobilization of an already existing population of memory cells, rather than a primary B-cell response. SARS-CoV-2-reactive CD4+ $\mathrm{T}$ cells were found in about $40-60 \%$ of people who had not been exposed to the virus, which suggests cross-recognition by memory cells of both common "cold" coronaviruses and SARS-CoV-2 [70]. If pre-existing cross-reactive IgE antibodies to cold viruses and/or relevant populations of memory B cells are also present in the blood, this can increase dysfunctional degranulation of mast cells. Antibodies produced by an early and rapid humoral response can also stimulate mast cell degranulation. During this phase, an increase in the level of D-dimers correlates with the level of CRP and IL-6, and ultimately with a severe outcome of the disease.

The researchers of the Immunology Department of the Institute of Experimental Medicine (St. Petersburg, Russia) have shown that Fc-gamma receptors of mast cells ensure their activation and release of histamine not only under the influence of IgG-containing immune complexes, but also under the influence of CRP, which binds to these receptors [71]. This finding explains the mechanism of the development of allergic reactions in inflammatory processes in a non-immunocomplex way. Thus, any acute phase reaction is fraught with the activation of mast cells and the occurrence of allergic, and possibly anaphylactic reactions. This conclusion is important both theoretically and practically, because indicates the direction for the development of new methods of pharmacological prevention of allergic complications in inflammatory diseases of children and adults. Vaccination is undoubtedly among the risk factors for such complications, since the inflammatory response of the body to the vaccine in the presence of a relatively high titer of $\mathrm{IgG}$ antibodies can provoke a redistribution of mast cells and the release of histamine, which can lead to activation of EC, the release of $\mathrm{vWF}$, followed by thrombosis.

The development of drugs for the therapy of COVID-19 is one of the main problems of modern pharmacology. The main efforts are directed to the development of etiotropic therapy, because the drugs of this series available to pharmacologists (remdesivir and various monoclonal antibodies) have a significant drawback: they must be administered intravenously. In early 2021, it was shown that the ribonucleoside analogue molnupiravir blocks the transmission of SARS-CoV-2 in ferrets [72]. And already in early October 2021, Ridgeback Biotherapeutics and Merck announced that their drug molnupiravir reduced hospital admissions among high-risk patients with COVID- 19 by $50 \%$ and significantly reduced mortality [73]. Molnupiravir can be taken orally twice a day for five days. More recently, AstraZeneca announced that its "cocktail of antibodies" prevents the severe form of COVID-19 [74]. It is known that the effectiveness of etiotropic 
therapy largely depends on the timely start.

Given the available information on the involvement of mast cells and the role of histamine in the pathogenesis of COVID-19, the development of pathogenetic therapy using $\mathrm{H} 2$-receptor antagonists appears to be a much more reliable prospect. According to the first reports published in the popular scientific press and based on unverified data from China [75], only famotidine provided a clinical effect in the treatment of COVID-19, while other H2-receptor antagonists (for example, cimetidine) did not. This fact made it possible to suggest that famotidine acts not only on H2-receptors. In particular, its binding to sigma receptors was tested, along with the possible inhibition of SARS-CoV-2 replication [8]. The mechanism of neutralization of SARS-CoV-2 through the direct interaction of famotidine with the active centers of viral proteases, in particular, with the papainlike protease PLpro and the 3-chymotrypsin-like protease Mpro, was also discussed [76, 77]. According to other researchers, this mechanism of action of famotidine as a component of etiotropic therapy is not proven, and the search for real mechanisms of its positive effect should be carried out from the standpoint of pathogenetic therapy, taking into account, first of all, the interaction of famotidine with $\mathrm{H} 2$-receptors [78]. At the same time, discussion of the efficacy of famotidine as an antagonist of $\mathrm{H} 2$-receptors often boils down to a discussion of its antacid properties associated with inhibition of the proton pump [79-81].

As a result of a comprehensive study, it was found that famotidine does not bind to the SARSCoV-2 proteases and does not suppress the activity of SARS-CoV-2 in other way, as a result of direct interaction with it. The action of famotidine is not mediated by sigma- $1 / 2$ receptors neither; however, the high selectivity of famotidine for H2-receptors with an affinity of about $14 \mathrm{nM}$ was confirmed, which is a significantly higher affinity of cimetidine for H2-receptors (590 nM). Additionally, it was found that famotidine is an inverse agonist of $\mathrm{H} 2$-receptor, and, unlike cimetidine, blocks Gs-protein signaling by recruiting arrestin [8, 82]. These features of famotidine fundamentally distinguish it from cimetidine and, possibly, from other H2-receptor blockers; the pronounced activation of arrestin by antagonists of G-protein-coupled receptors (GPCR) is not unique, however is not widespread. In addition, famotidine abolished $\mathrm{H} 2-$ receptor-mediated negative effects on cytokine production, especially $\mathrm{TNF}-\alpha$ and interferon $-\gamma$, reducing lipopolysaccharide-induced TNF- $\alpha$ production and B7-1 expression on monocytes, as well as inhibitory effects of histamine on Th1mediated release cytokines.

Another point of application of famotidine is a decrease in neutrophil reactivity [83]. Innate cellular immunity is the most important element of antiviral defense. Neutrophils not only serve as a marker of acute infection, but also serve as a source of neutrophil extracellular traps (NET), playing a key role in the development of thrombotic complications due to the so-called NETotic transformation. In samples of the lungs, kidneys and hearts of patients who died due to COVID-19, microvascular thrombi contained a large number of neutrophils [83, 84]. ROS of neutrophils are considered to be a trigger of NETosis, but antagonists of H2-receptors, including famotidine and cimetidine, reduce neutrophil activation and its consequences [85]. Famotidine dosedependently reduces the level of intracellular calcium in neutrophils and the intensity of ROS generation [86]. This fact explains the clinical observations according to which famotidine reduces the level of D-dimers and the likelihood of developing pulmonary embolism in COVID-19 $[83,86]$.

Nevertheless, information on the effectiveness of famotidine in the treatment of patients with COVID-19 in a clinical setting is rather contradictory: along with sufficiently convincing data on its positive effect $[87,88]$, there is no less convincing information about the lack of effectiveness of this drug [89-92]. However, it is important to note that the dose of intravenous famotidine used in multicenter clinical trial MATCH (Molecular Analysis for Therapy Choice) was $360 \mathrm{mg} /$ day. This dose is almost 10 times higher than the oral dose of famotidine, usually used in the treatment of peptic ulcer disease [75, 93], while its positive effects have been noted when taken orally at doses of 20-40 mg/day [87]. Moreover, in MATCH study, the use of famotidine was accompanied by the use of $200 \mathrm{mg}$ hydroxychloroquine in the con- 
trol and experimental groups. Although famotidine is a proven safe drug, excessive suppression of gastric acid secretion can cause pneumonia [94].

If the pathogenesis of COVID-19 is associated with dysfunctional degranulation of mast cells, then the use of a variety of pharmaceuticals used to treat diseases associated with mast cells will help reduce the mortality and severity of diseases associated with SARS-CoV-2 infection. These include drugs that stabilize the activity of mast cells, such as: antagonists of beta-2-adrenergic receptors [95] and cromolyn sodium (cromoglicic acid) [96, 97], other histamine antagonists (for example, H1 and H4) [49, 98, 99], antagonists of leukotriene receptors [100], anti-inflammatory agents used in intestinal diseases and inhibitors of mast cell activation [101, 102]. If such agents are used in combination with pharmaceuticals that directly suppress the replication of SARS-CoV-2, then it will be possible to develop effective, safe and effective outpatient methods for the prevention and pathogenetic therapy of COVID-19.

\section{CONCLUSION}

The use of famotidine in combination with oseltamivir as a means of pathogenetic therapy when mice are infected with the viral strain A/ $\mathrm{PR} / 8 / 34$, which causes a disease in mice similar to COVID-19 in humans, increases survival, improves the dynamics of animal body weight, and helps to reduce the level of NKT-cells and an increase in the level of naive T-helpers. Further studies of famotidine in vivo should be aimed at optimizing the regimen of drug use at a higher viral load, based on the fact that the effect on animal survival will be more noticeable with the corresponding indicators in the comparison groups not exceeding $50 \%$, as well as with a longer use of famotidine.

\section{AUTHORS' CONTRIBUTION}

Conceptualization (N.V.G. and P.V.A.), collection of literature data and experiment planning (all authors), investigation and data analysis (K.A.V., I.V.K., M.A.S.), manuscript preparation and editing (N.V.G., D.A.B., P.V.A.).

\section{FUNDING}

These studies were supported by the Russian Science Foundation, project no. 21-15-00441.

\section{CONFLICTS OF INTEREST}

The authors declare no obvious and potential conflicts of interest related to the publication of this article.

\section{REFERENCES}

1. Amraei R, Rahimi N (2020) COVID-19, ReninAngiotensin System and Endothelial Dysfunction. Cells 9:1652. https://doi.org/10.3390/cells9071652

2. Spiezia L, Boscolo A, Poletto F, Cerruti L, Tiberio I, Campello E, Navalesi P, Simioni P (2020) COVID-19-Related Severe Hypercoagulability in Patients Admitted to Intensive Care Unit for Acute Respiratory Failure. Thromb Haemost 120:998-1000. https://doi.org/10.1055/s-00401710018

3. Tang N, Li D, Wang X, Sun Z (2020) Abnormal coagulation parameters are associated with poor prognosis in patients with novel coronavirus pneumonia. J Thromb Haemost 18:844-847. https:// doi.org/10.1111/jth.14768

4. Vaduganathan M, Vardeny O, Michel T, McMurray JJV, Pfeffer MA, Solomon SD (2020) ReninAngiotensin-Aldosterone System Inhibitors in Patients with Covid-19. N Engl J Med 382:16531659. https://doi.org/10.1056/NEJMsr2005760

5. Amraei R, Yin W, Napoleon MA, Suder EL, Berrigan J, Zhao Q, Olejnik J, Chandler KB, Xia C, Feldman J, Hauser BM, Caradonna TM, Schmidt AG, Gummuluru S, Mühlberger E, Chitalia V, Costello CE, Rahimi N (2021) CD209L/ L-SIGN and CD209/DC-SIGN Act as Receptors for SARS-CoV-2. ACS Cent Sci 7:1156-1165. https://doi.org/10.1021/acscentsci.0c01537

6. Daly JL, Simonetti B, Klein K, Chen KE, Williamson MK, Antyn-Plágaro C, Shoemark DK, Simyn-Gracia L, Bauer M, Hollandi R, Greber UF, Horvath P, Sessions RB, Helenius A, Hiscox JA, Teesalu T, Matthews DA, Davidson AD, Collins BM, Cullen PJ, Yamauchi Y (2020) Neuropilin-1 is a host factor for SARS-CoV-2 infection. Science 370:861-865. https://doi.org/10.1126/science.abd3072

7. Wang K, Chen W, Zhang Z, Deng Y, Lian JQ, Du P, Wei D, Zhang Y, Sun XX, Gong L, 
Yang $\mathrm{X}$, He L, Zhang L, Yang Z, Geng JJ, Chen R, Zhang H, Wang B, Zhu YM, Nan G, Jiang JL, Li L, Wu J, Lin P, Huang W, Xie L, Zheng ZH, Zhang K, Miao JL, Cui HY, Huang M, Zhang J, Fu L, Yang XM, Zhao Z, Sun S, Gu H, Wang Z, Wang CF, Lu Y, Liu YY, Wang QY, Bian H, Zhu P, Chen ZN (2020) CD147-spike protein is a novel route for SARSCoV-2 infection to host cells. Signal Transduct Target Ther 5: 283. https://doi.org/10.1038/ s41392-020-00426-X

8. Malone RW, Tisdall P, Fremont-Smith P, Liu Y, Huang XP, White KM, Miorin L, Moreno E, Alon A, Delaforge E, Hennecker CD, Wang G, Pottel J, Blair RV, Roy CJ, Smith N, Hall JM, Tomera KM, Shapiro G, Mittermaier A, Kruse AC, García-Sastre A, Roth BL, GlasspoolMalone J, Ricke DO (2021) COVID-19: Famotidine, Histamine, Mast Cells, and Mechanisms. Front Pharmacol 12:633680. https://doi.org/ 10.3389/fphar.2021.633680

9. Eliezer M, Hautefort C, Hamel AL, Verillaud B, Herman P, Houdart E, Eloit C (2020) Sudden and Complete Olfactory Loss of Function as a Possible Symptom of COVID-19. JAMA Otolaryngol Head Neck Surg 146:674-675. https://doi.org/ 10.1001/jamaoto.2020.0832

10. Mehta P, McAuley DF, Brown M, Sanchez E, Tattersall RS, Manson JJ, HLH Across Speciality Collaboration UK (2020) COVID-19: consider cytokine storm syndromes and immunosuppression. Lancet 395:1033-1034. https://doi.org/ 10.1016/S0140-6736(20)30628-0

11. Fung SY, Yuen KS, Ye ZW, Chan CP, Jin DY (2020) A tug-of-war between severe acute respiratory syndrome coronavirus 2 and host antiviral defence: lessons from other pathogenic viruses. Emerg Microbes Infect 9:558-570. https:// doi.org/10.1080/22221751.2020.1736644

12. von Moltke J, Trinidad NJ, Moayeri M, Kintzer AF, Wang SB, van Rooijen N, Brown CR, Krantz BA, Leppla SH, Gronert K, Vance RE (2012) Rapid induction of inflammatory lipid mediators by the inflammasome in vivo. Nature 490:107-111. https://doi.org/10.1038/ nature 11351

13. Serhan CN (2014) Pro-resolving lipid mediators are leads for resolution physiology. Nature 510:92-101. https://doi.org/10.1038/ nature 13479

14. Panigrahy D, Gilligan MM, Huang S, Gartung A, Cortés-Puch I, Sime PJ, Phipps RP, Serhan CN, Hammock BD (2020) Inflammation resolution: a dual-pronged approach to averting cytokine storms in COVID-19? Cancer Metastasis Rev 39:337-340. https://doi.org/10.1007/s10555020-09889-4

15. Obara I, Telezhkin V, Alrashdi I, Chazot PL (2020) Histamine, histamine receptors, and neuropathic pain relief. Br J Pharmacol 177:580-599. https://doi.org/10.1111/bph.14696

16. Hattori M, Yamazaki M, Ohashi W, Tanaka S, Hattori K, Todoroki K, Fujimori T, Ohtsu H, Matsuda N, Hattori Y (2016) Critical role of endogenous histamine in promoting end-organ tissue injury in sepsis. Intensive Care Med Exp 4:36. https://doi.org/10.1186/s40635-016-0109-y

17. Merad M, Martin JJC (2020) Pathological inflammation in patients with COVID-19: a key role for monocytes and macrophages. Nat Rev Immunol 20:355. https://doi.org/10.1038/ s41577-020-0331-4

18. Vabret N, Britton GJ, Gruber C, Hegde S, Kim J, Kuksin M, Levantovsky R, Malle L, Moreira A, Park MD, Pia L, Risson E, Saffern M, Salomé B, Esai Selvan M, Spindler MP, Tan J, van der Heide V, Gregory JK, Alexandropoulos K, Bhardwaj N, Brown BD, Greenbaum B, Gümüş ZH, Homann D, Horowitz A, Kamphorst AO, Curotto de Lafaille MA, Mehandru S, Merad M, Samstein RM, Sinai Immunology Review Project (2020) Immunology of COVID-19: Current State of the Science. Immunity 52:910-941. https://doi.org/10.1016/ j.immuni.2020.05.002

19. McGonagle D, O'Donnell JS, Sharif K, Emery P, Bridgewood C (2020) Immune mechanisms of pulmonary intravascular coagulopathy in COVID-19 pneumonia. Lancet Rheumatol 2:437-445. https://doi.org/10.1016/S26659913(20)30121-1

20. Kritas S, Ronconi G, Caraffa A, Gallenga C, Ross R, Conti P (2019) Mast cells contribute to coronavirus-induced inflammation: new antiinflammatory strategy. J Biol Regul Homeost Agents 34:9-14. https://doi.org/10.23812/20Editorial-Kritas

21. Conti P, Caraffa A, Теtи G, Gallenga CE, Ross R, Kritas SK, Frydas I, Younes A, Di Emidio P, Ronconi G (2020) Mast cells activated by SARS-CoV-2 release histamine which increases IL-1 levels causing cytokine storm and inflammatory reaction in COVID-19. J Biol Regul Homeost Agents 34:1629-1632. https://doi.org/ 10.23812/20-2EDIT

22. Afrin LB, Ackerley MB, Bluestein LS, Brewer JH, Brook JB, Buchanan AD, Cuni JR, Davey WP, Dempsey TT, Dorff SR, Dubravec MS, Guggen- 
heim AG, Hindman KJ, Hoffman B, Kaufman DL, Kratzer SJ, Lee TM, Marantz MS, Maxwell AJ, McCann KK, McKee DL, Menk Otto L, Pace LA, Perkins DD, Radovsky L, Raleigh MS, Rapaport SA, Reinhold EJ, Renneker ML, Robinson WA, Roland AM, Rosenbloom ES, Rowe PC, Ruhoy IS, Saperstein DS, Schlosser DA, Schofield JR, Settle JE, Weinstock LB, Wengenroth M, Westaway M, Xi SC, Molderings GJ (2020) Diagnosis of mast cell activation syndrome: a global "consensus-2". Diagnosis (Berl) 8:137-152. https://doi.org/ $10.1515 / \mathrm{dx}-2020-0005$

23. Weiler CR (2020) Mast cell activation syndrome: tools for diagnosis and differential diagnosis. J Allergy Clin Immunol Pract 8:498-506. https:// doi.org/10.1016/j.jaip.2019.08.022

24. Weinstock LB, Pace LA, Rezaie A, Afrin LB, Molderings GJ (2020) Mast cell activation syndrome: a primer for the gastroenterologist. Dig Dis Sci 66:965-982. https://doi.org/10.1007/ s10620-020-06264-9

25. Mongkolsapaya J, Dejnirattisai W, Xu XN, Vasanawathana S, Tangthawornchaikul N, Chairunsri A, Sawasdivorn S, Duangchinda T, Dong T, Rowland-Jones S, Yenchitsomanus PT, McMichael A, Malasit P, Screaton G (2003) Original antigenic sin and apoptosis in the pathogenesis of dengue hemorrhagic fever. Nat Med 9:921-927. https://doi.org/10.1038/nm887

26. Redoni M, Yacoub S, Rivino L, Giacobbe DR, Luzzati R, Di Bella S (2020) Dengue: status of current and under-development vaccines. Rev Med Virol 30:2101. https://doi.org/10.1002/ rmv. 2101

27. Kounis NG (2016) Kounis syndrome: an update on epidemiology, pathogenesis, diagnosis and therapeutic management. Clin Chem Lab Med 54:1545-1559. https://doi.org/10.1515/cclm2016-0010

28. Motta Junior JDS, Miggiolaro AFRDS, Nagashima S, de Paula CBV, Baena CP, Scharfstein J, de Noronha L (2020) Mast Cells in Alveolar Septa of COVID-19 Patients: A Pathogenic Pathway That May Link Interstitial Edema to Immunothrombosis. Front Immunol 11:574862. https://doi.org/10.3389/fimmu.2020.574862

29. de Wit E, Munster VJ, Spronken MI, Bestebroer TM, Baas C, Beyer WE, Rimmelzwaan GF, Osterhaus AD, Fouchier RA (2005) Protection of mice against lethal infection with highly pathogenic H7N7 influenza A virus by using a recombinant low-pathogenicity vaccine strain. J Virol 79:12401-12407. https://doi.org/
10.1128/JVI.79.19.12401-12407.2005

30. Li C, Xu LJ, Lian WW, Pang XC, Jia H, Liu AL, Du GH (2018) Anti-influenza effect and action mechanisms of the chemical constituent gallocatechin-7-gallate from Pithecellobium clypearia Benth. Acta Pharmacol Sin 39:1913-1922. https:// doi.org/10.1038/s41401-018-0030-X

31. Golde W, Gollobin P, Rodriguez L (2005) A rapid, simple, and humane method for submandibular bleeding of mice using a lancet. Lab Anim 34:39-43. https://doi.org/10.1038/laban1005-39

32. Bai L, Deng S, Reboulet R, Mathew R, Teyton L, Savage PB, Bendelac A (2013) Natural killer T (NKT)-B-cell interactions promote prolonged antibody responses and long-term memory to pneumococcal capsular polysaccharides. Proc Natl Acad Sci USA 110:16097-16102. https:// doi.org/10.1073/pnas.1303218110

33. Kim DM, Seo JW, Kim Y, Park U, Ha NY, Park H, Yun NR, Kim DY, Yoon SH, Na YS, Moon DS, Lim SC, Kim CM, Kim YS, Cho NH (2021) Eosinophil-mediated lung inflammation associated with elevated natural killer $\mathrm{T}$ cell response in COVID-19 patients. Korean J Intern Med Online ahead of print. https://doi.org/ 10.3904/kjim.2021.093

34. Qin C, Zhou L, Hu Z, Zhang S, Yang S, Tao Y, Xie C, Ma K, Shang K, Wang W, Tian DS (2020) Dysregulation of Immune Response in Patients With Coronavirus 2019 (COVID-19) in Wuhan, China. Clin Infect Dis 71:762-768. https:// doi.org/10.1093/cid/ciaa248

35. Notz Q, Schmalzing M, Wedekink F, Schlesinger T, Gernert M, Herrmann J, Sorger L, Weismann D, Schmid B, Sitter M, Schlegel N, Kranke P, Wischhusen J, Meybohm P, Lotz C (2020) Pro- and Anti-Inflammatory Responses in Severe COVID-19-Induced Acute Respiratory Distress Syndrome-An Observational Pilot Study. Front Immunol 11:581338. https://doi.org/ 10.3389/fimmu.2020.581338

36. Li Y, Zhou W, Yang L, You R (2020) Physiological and pathological regulation of ACE2, the SARS-CoV-2 receptor. Pharmacol Res 157: 104833. https://doi.org/10.1016/ j.phrs.2020.104833

37. Guan WJ, Ni ZY, Hu Y, Liang WH, Ou CQ, He JX, Liu L, Shan H, Lei CL, Hui DSC, Du B, Li LJ, Zeng G, Yuen KY, Chen RC, Tang CL, Wang T, Chen PY, Xiang J, Li SY, Wang JL, Liang ZJ, Peng YX, Wei L, Liu Y, Hu YH, Peng P, Wang JM, Liu JY, Chen Z, Li G, Zheng ZJ, Qiu SQ, Luo J, Ye CJ, Zhu SY, Zhong NS; China Medical Treatment Expert 
Group for Covid-19 (2020) Clinical Characteristics of Coronavirus Disease 2019 in China. N Engl J Med 382:1708-1720. https://doi.org/10.1056/ NEJMoa2002032

38. Qiu Y, Zheng F, Ye C, Chen AD, Wang JJ, Chen Q, Li YH, Kang YM, Zhu GQ (2020) Angiotensin Type 1 Receptors and Superoxide Anion Production in Hypothalamic Paraventricular Nucleus Contribute to Capsaicin-Induced Excitatory Renal Reflex and Sympathetic Activation. Neurosci Bull 36:463-474. https://doi.org/ 10.1007/s12264-019-00460-y

39. Bernstein KE, Khan Z, Giani JF, Cao DY, Bernstein EA, Shen XZ (2018) Angiotensin-converting enzyme in innate and adaptive immunity. Nat Rev Nephrol 14:325-336. https://doi.org/10.1038/ nrneph.2018.15

40. Tian $\mathrm{S}, \mathrm{Hu} \mathrm{W}$, Niu L, Liu $\mathrm{H}, \mathrm{Xu} \mathrm{H}$, Xiao SY (2020) Pulmonary pathology of early-phase 2019 novel coronavirus (COVID-19) pneumonia in two patients with lung cancer. $\mathbf{J}$ Thorac Oncol 15:700-704. https://doi.org/10.1016/ j.jtho.2020.02.010

41. Gespach C, Abita JP (1982) Human polymorphonuclear neutrophils. Pharmacological characterization of histamine receptors mediating the elevation of cyclic AMP. Mol Pharmacol 21:78-85.

42. Burde R, Seifert R, Buschauer A, Schultz G (1989) Histamine inhibits activation of human neutrophils and HL-60 leukemic cells via H2receptors. Arch Pharmacol 340:671-678. https:// doi.org/10.1007/BF00717743

43. Rabier $M$, Damon $M$, Chanez $P$, MenciaHuerta JM, Braquet P, Bousquet J, Michel FB, Godard P (1989) Inhibition by histamine of platelet-activating-factor-induced neutrophil chemotaxis in bronchial asthma. Int Arch Allergy Appl Immunol 89:314-317. https://doi.org/10.1159/ 000234967

44. Flamand N, Plante H, Picard S, Laviolette M, Borgeat P (2004) Histamine-induced inhibition of leukotriene biosynthesis in human neutrophils: involvement of the $\mathrm{H} 2$ receptor and cAMP. Br J Pharmacol 141:552-561. https://doi.org/ 10.1038/sj.bjp.0705654

45. Ezeamuzie CI, Philips E (2000) Histamine H(2) receptors mediate the inhibitory effect of histamine on human eosinophil degranulation. $\mathrm{Br} \mathrm{J}$ Pharmacol 131:482-488. https://doi.org/ 10.1038/sj.bjp.0703556

46. Wadee AA, Anderson R, Sher R (1980) In vitro effects of histamine on eosinophil migration. Int Arch Allergy Appl Immunol 63:322-329. https:// doi.org/10.1159/000232643
47. Tian $\mathrm{S}, \mathrm{Hu} \mathrm{W}$, Niu L, Liu H, Xu H, Xiao SY (2020) Pulmonary pathology of early-phase 2019 novel coronavirus (COVID-19) pneumonia in two patients with lung cancer. J Thorac Oncol 15:700-704. https://doi.org/10.1016/ j.jtho.2020.02.010

48. Zeng Z, Xu L, Xie XY, Yan HL, Xie BJ, Xu WZ, Liu XA, Kang GJ, Jiang WL, Yuan JP (2020) Pulmonary pathology of early-phase COVID-19 pneumonia in a patient with a benign lung lesion. Histopathology 77:823-831. https://doi.org/ 10.1111/his. 14138

49. Marone G, Columbo M, Triggiani M, Vigorita S, Formisano S (1986) Forskolin inhibits the release of histamine from human basophils and mast cells. Agents Actions 18:96-99. https://doi.org/ 10.1007/BF01987993

50. Bissonnette EY (1996) Histamine inhibits tumor necrosis factor alpha release by mast cells through $\mathrm{H} 2$ and $\mathrm{H} 3$ receptors. Am J Respir Cell Mol Biol 14:620-626. https://doi.org/10.1165/ ajrcmb.14.6.8652190

51. Couzin-Frankel J (2020) The mystery of the pandemic's 'happy hypoxia'. Science 368:455-456. https://doi.org/10.1126/science.368.6490.455

52. Schweitzer W, Ruder T, Baumeister R, Bolliger S, Thali M, Meixner E, Ampanozi G (2020) Implications for forensic death investigations from first Swiss post-mortem CT in a case of non-hospital treatment with COVID-19. Forensic Imaging 21:200378. j.fri.2020.200378 https://doi.org/10.1016/

53. Cohen PA, Hall L, Johns JN, Rapoport AB (2020) The early natural history of SARS-CoV-2 infection: clinical observations from an urban, ambulatory COVID-19 clinic. Mayo Clin Proc 95:1124. https://doi.org/10.1016/ j.mayocp. 2020.04 .010

54. Gattinoni L, Chiumello D, Rossi S (2020) COVID-19 pneumonia: ARDS or not? Crit Care 24:154. https://doi.org/10.1186/s13054-02002880-Z

55. Filatov A, Sharma P, Hindi F, Espinosa PS (2020) Neurological complications of coronavirus disease (COVID-19): encephalopathy. Cureus 12:7352. https://doi.org/10.7759/cureus.7352

56. Mao L, Jin H, Wang M, Hu Y, Chen S, He Q, Chang J, Hong C, Zhou Y, Wang D, Miao X, Li Y, Hu B (2020) Neurologic Manifestations of Hospitalized Patients With Coronavirus Disease 2019 in Wuhan, China. JAMA Neurol 77:683$690 . \quad$ https://doi.org/10.1001/jamaneurol.2020.1127

57. Qureshi AI, Abd-Allah F, Al-Senani F, Aytac E, 
Borhani-Haghighi A, Ciccone A, Gomez CR, Gurkas E, Hsu CY, Jani V, Jiao L, Kobayashi A, Lee J, Liaqat J, Mazighi M, Parthasarathy R, Steiner T, Suri MFK, Toyoda K, Ribo M, Gongora-Rivera F, Oliveira-Filho J, Uzun G, Wang Y (2020) Management of acute ischemic stroke in patients with COVID-19 infection: Report of an international panel. Int J Stroke 15:540-554. https://doi.org/10.1177/1747493020923234

58. Long B, Brady WJ, Koyfman A, Gottlieb M (2020) Cardiovascular complications in COVID19. Am J Emerg Med 38:1504. https://doi.org/ 10.1016/j.ajem.2020.04.048

59. Mahmud E, Dauerman HL, Welt FGP, Messenger JC, Rao SV, Grines C, Mattu A, Kirtane AJ, Jauhar R, Meraj P, Rokos IC, Rumsfeld JS, Henry TD (2020) Management of Acute Myocardial Infarction During the COVID-19 Pandemic: A Position Statement From the Society for Cardiovascular Angiography and Interventions (SCAI), the American College of Cardiology (ACC), and the American College of Emergency Physicians (ACEP). J Am Coll Cardiol 76:13751384. https://doi.org/10.1016/j.jacc.2020.04.039

60. Du Y, Guo M, Whitsett JA, Xu Y (2015) Lung GENS': a web-based tool for mapping single-cell gene expression in the developing lung. Thorax 70:1092-1094. https://doi.org/10.1136/thoraxjnl-2015-207035

61. Di Lorenzo A, Fernandez-Hernando C, Cirino G, Sessa WC (2009) Akt1 is critical for acute inflammation and histamine-mediated vascular leakage. Proc Natl Acad Sci USA 106:14552-14557. https://doi.org/10.1073/ pnas.0904073106

62. Panula P, Chazot PL, Cowart M, Gutzmer R, Leurs R, Liu WL, Stark H, Thurmond RL, Haas HL (2015) International union of basic and clinical pharmacology. XCVIII. Histamine receptors. Pharmacol Rev 67:601-655. https://doi.org/ 10.1124/pr.114.010249

63. Luo T, Chen B, Zhao Z, He N, Zeng Z, Wu B, Fukushima Y, Dai M, Huang Q, Xu D, Bin J, Kitakaze M, Liao Y (2013) Histamine H2 receptor activation exacerbates myocardial ischemia/ reperfusion injury by disturbing mitochondrial and endothelial function. Basic Res Cardiol 108:342. https://doi.org/10.1007/s00395-013-0342-4.

64. Sakurai E (2020) Elucidation of New Function in Endothelial Cells for Efficient Delivery Strategy of Drug to Tissues. Yakugaku Zasshi 140:51-62. [In Japan]. $\quad$ https://doi.org/10.1248/yakushi.1900179

65. Avdonin PV, Rybakova EY, Avdonin PP, Tru- fanov SK, Mironova GY, Tsitrina AA, Goncharov NV (2019) VAS2870 Inhibits Histamine-Induced Calcium Signaling and vWF Secretion in Human Umbilical Vein Endothelial Cells. Cells 8:196. https://doi.org/10.3390/cells8020196

66. Vlahos R, Stambas J, Bozinovski S, Broughton BR, Drummond GR, Selemidis S (2011) Inhibition of Nox2 oxidase activity ameliorates influenza A virus-induced lung inflammation. PLoS Pathog 7:1001271. https://doi.org/ 10.1371/journal.ppat.1001271

67. Carsana L, Sonzogni A, Nasr A, Rossi RS, Pellegrinelli A, Zerbi P, Rech R, Colombo R, Antinori S, Corbellino M, Galli M, Catena E, Tosoni A, Gianatti A, Nebuloni M (2020) Pulmonary post-mortem findings in a large series of COVID-19 cases from Northern Italy. medRxiv 20:1132-1140. https://doi.org/10.1101/ 2020.04.19.20054262

68. Magro C, Mulvey JJ, Berlin D, Nuovo G, Salvatore S, Harp J, Baxter-Stoltzfus A, Laurence J (2020) Complement associated microvascular injury and thrombosis in the pathogenesis of severe COVID-19 infection: A report of five cases. Transl Res 220:1-13. https://doi.org/10.1016/ j.trsl.2020.04.007

69. Panigada M, Bottino N, Tagliabue P, Grasselli G, Novembrino C, Chantarangkul V, Pesenti A, Peyvandi F, Tripodi A (2020) Hypercoagulability of COVID-19 patients in intensive care unit: A report of thromboelastography findings and other parameters of hemostasis. J Thromb Haemost 18:1738-1742. https://doi.org/10.1111/jth.14850

70. Grifoni A, Weiskopf D, Ramirez SI, Mateus J, Dan JM, Moderbacher CR, Rawlings SA, Sutherland A, Premkumar L, Jadi RS, Marrama D, de Silva AM, Frazier A, Carlin AF, Greenbaum JA, Peters B, Krammer F, Smith DM, Crotty S, Sette A (2020) Targets of T Cell Responses to SARS-CoV-2 Coronavirus in Humans with COVID-19 Disease and Unexposed Individuals. Cell 181:1489-1501.e15. https://doi.org/ 10.1016/j.cell.2020.05.015

71. Trulioff SA, Kudryavtsev IV, Nazarov PG (2012) Factors of the acute phase of inflammation as modulators of the interaction of mast cells and fibroblasts. Acta Biomedica Scientifica 3:319322. (In Russ).

72. Cox RM, Wolf JD, Plemper RK (2021) Therapeutically administered ribonucleoside analogue MK-4482/EIDD-2801 blocks SARS-CoV-2 transmission in ferrets. Nat Microbiol 6:11-18. https://doi.org/10.1038/s41564-020-00835-2

73. Herper M (2021) What we know-and don't 
know-about Merck's new Covid-19 pill. https:// www.statnews.com/2021/10/04/what-we-knowand-dont-know-about-mercks-new-covid-19pill/. Accessed 18 Dec. 2021.

74. BMJ (2021) Covid-19: AstraZeneca says its antibody drug AZD7442 is effective for preventing and reducing severe illness.: BMJ 375:n2860. https:// doi.org/10.1136/bmj.n2860

75. Borrell B (2020) New York clinical trial quietly tests heartburn remedy against coronavirus [Online]. Science Magazine. https://doi.org/ $10.1126 /$ science.abc4739

76. Ortega JT, Serrano ML, Jastrzebska B (2020) Class A G Protein-Coupled Receptor Antagonist Famotidine as a Therapeutic Alternative Against SARS-CoV2: An In Silico Analysis. Biomolecules 10:954. https://doi.org/10.3390/biom10060954

77. Wu C, Liu Y, Yang Y, Zhang $\mathrm{P}$, Zhong W, Wang Y, Wang Q, Xu Y, Li M, Li X, Zheng M, Chen L, Li H (2020) Analysis of therapeutic targets for SARS-CoV-2 and discovery of potential drugs by computational methods. Acta Pharm Sin B 10:766-788. https://doi.org/10.1016/ j.apsb.2020.02.008

78. Singh VP, El-Kurdi B, Rood C (2021) What Underlies the Benefit of Famotidine Formulations Used During COVID-19? Gastroenterology 160:1899-1900. https://doi.org/10.1053/j.gastro.2020.07.051

79. Mura C, Preissner S, Preissner R, Bourne PE (2021) A Birds-Eye (Re)View of Acid-Suppression Drugs, COVID-19, and the Highly Variable Literature. Front Pharmacol 12:700703. https:// doi.org/10.3389/fphar.2021.700703

80. Jimenez L, Campos Codo A, Sampaio VS, Oliveira AER, Ferreira LKK, Davanzo GG, de Brito Monteiro L, Victor Virgilio-da-Silva J, Borba MGS, Fabiano de Souza G, Zini N, de Andrade Gandolfi F, Muraro SP, Luiz ProençaModena J, Val FA, Cardoso Melo G, Monteiro WM, Nogueira ML, Lacerda MVG, Moraes-Vieira PM, Nakaya HI (2021) Acid pH Increases SARS-CoV-2 Infection and the Risk of Death by COVID-19. Front Med (Lausanne) $8: 637885$. fmed.2021.637885

81. Shoaibi A, Fortin SP, Weinstein R, Berlin JA, Ryan P (2021) Comparative Effectiveness of Famotidine in Hospitalized COVID-19 Patients. Am J Gastroenterol 116:692-699. https:// doi.org/10.14309/ajg.0000000000001153

82. Alonso N, Zappia CD, Cabrera M, Davio CA, Shayo C, Monczor F, Fernández NC (2015) Physiological implications of biased signaling at histamine $\mathrm{H}_{2}$ receptors. Front Pharmacol 6:45. https://doi.org/10.3389/fphar.2015.00045

83. Radermecker C, Detrembleur N, Guiot J, Cavalier E, Henket M, d'Emal C, Vanwinge C, Cataldo D, Oury C, Delvenne P, Marichal T. Neutrophil extracellular traps infiltrate the lung airway, interstitial, and vascular compartments in severe COVID-19 (2020) J Exp Med 217:20201012. $\quad$ https://doi.org/10.1084/ jem.20201012

84. Nicolai L, Leunig A, Brambs S, Kaiser R, Weinberger $T$, Weigand $M$, Muenchhoff $M$, Hellmuth JC, Ledderose S, Schulz H, Scherer C, Rudelius M, Zoller M, Höchter D, Keppler O, Teupser D, Zwißler B, von Bergwelt-Baildon M, Kääb S, Massberg S, Pekayvaz K, Stark K (2020) Immunothrombotic Dysregulation in COVID-19 Pneumonia Is Associated With Respiratory Failure and Coagulopathy. Circulation 142:11761189. https://doi.org/10.1161/CIRCULATIONAHA. 120.048488

85. Mikawa K, Akamatsu H, Nishina K, Shiga M, Maekawa N, Obara H, Niwa Y (1999) The effects of cimetidine, ranitidine, and famotidine on human neutrophil functions. Anesth Analg 89:218-224. https://doi.org/10.1097/00000539199907000-00040

86. Tomera K, Malone R, Kittah J (2020) Hospitalized COVID-19 Patients Treated With Celecoxib and High Dose Famotidine Adjuvant Therapy Show Significant Clinical Responses [Online]. SSRN. https://doi.org/10.2139/ssrn.3646583

87. Freedberg DE, Conigliaro J, Wang TC, Tracey KJ, Callahan MV, Abrams JA, Famotidine Research Group (2020) Famotidine Use Is Associated With Improved Clinical Outcomes in Hospitalized COVID-19 Patients: A Propensity Score Matched Retrospective Cohort Study. Gastroenterology 159:1129-1131.e3. https://doi.org/ $10.1053 /$ j.gastro.2020.05.053

88. Mather JF, Seip RL, McKay RG (2020) Impact of Famotidine Use on Clinical Outcomes of Hospitalized Patients With COVID-19. Am J Gastroenterol 115:1617-1623. https://doi.org/ 10.14309/ajg.0000000000000832

89. Kuno T, So M, Takahashi M, Egorova NN (2021) The association between famotidine and in-hospital mortality of patients with COVID-19. J Med Virol. Online ahead of print. https://doi.org/ 10.1002/jmv.27375

90. Sun $\mathrm{C}$, Chen Y, Hu L, Wu Y, Liang M, Ayaz Ahmed M, Bhan C, Guo Z, Yang H, Zuo Y, Yan Y, Zhou Q (2021) Does Famotidine Reduce the Risk of Progression to Severe Disease, Death, 
and Intubation for COVID-19 Patients? A Systemic Review and Meta-Analysis. Dig Dis Sci 66:3929-3937. https://doi.org/10.1007/s10620021-06872-Z

91. Cheung KS, Hung IFN, Leung WK (2021) Association Between Famotidine Use and COVID-19 Severity in Hong Kong: A Territory-wide Study. Gastroenterology 160:1898-1899. https:// doi.org/10.1053/j.gastro.2020.05.098

92. Shoaibi A, Fortin SP, Weinstein R, Berlin JA, Ryan P (2021) Comparative Effectiveness of Famotidine in Hospitalized COVID-19 Patients. Am J Gastroenterol 116:692-699. https:// doi.org/10.14309/ajg.0000000000001153

93. Conigliaro J (2020, April 7 - 2020, September 7) A Multi-site, Randomized, Double-Blind, Comparative Trial of the Safety and Efficacy of Standard of Care (SOC) Plus Famotidine vs SOC Plus Placebo for the Treatment of COVID-19 in Hospitalized Adults. Identifier NCT04370262. https:// clinicaltrials.gov/ct2/show/NCT04370262.

Accessed 18 Dec. 2021.

94. Eom CS, Jeon CY, Lim JW, Cho EG, Park SM, Lee KS (2011) Use of acid-suppressive drugs and risk of pneumonia: a systematic review and metaanalysis. CMAJ 183:310-319.

95. Scola AM, Chong LK, Suvarna SK, Chess-Williams R, Peachell PT (2004) Desensitisation of mast cell beta2-adrenoceptor-mediated responses by salmeterol and formoterol. $\mathrm{Br} \mathrm{J}$ Pharmacol 141:163-171. https://doi.org/10.1038/ sj.bjp.0705599

96. Zhang T, Finn DF, Barlow JW, Walsh JJ (2016) Mast cell stabilisers. Eur J Pharmacol 778:158168. https://doi.org/10.1016/j.ejphar.2015.05.071
97. Han D, Wei $\mathrm{T}$, Zhang $\mathrm{S}$, Wang $\mathrm{M}$, Tian $\mathrm{H}$, Cheng J, Xiao J, Hu Y, Chen M (2016) The therapeutic effects of sodium cromoglycate against influenza A virus $\mathrm{H} 5 \mathrm{~N} 1$ in mice. Influenza Other Respir Viruses 10:57-66. https://doi.org/ 10.1111/irv.12334

98. Okayama Y, Benyon RC, Lowman MA, Church MK (1994) In vitro effects of H1-antihistamines on histamine and PGD2 release from mast cells of human lung, tonsil, and skin. Allergy 49:246-253. https://doi.org/10.1111/j.13989995.1994.tb02657.x

99. Hogan Ii RB, Hogan Iii RB, Cannon T, Rappai M, Studdard J, Paul D, Dooley TP (2020) Dual-histamine receptor blockade with cetirizine-famotidine reduces pulmonary symptoms in COVID-19 patients. Pulm Pharmacol Ther 63:101942. j.pupt.2020.101942

100. Fidan C, Aydogdu A (2020) As a potential treatment of COVID-19: Montelukast. Med Hypotheses 142:109828. https://doi.org/10.1016/ j.mehy.2020.109828

101. Castells M, Butterfield J (2019) Mast Cell Activation Syndrome and Mastocytosis: Initial Treatment Options and Long-Term Management. J Allergy Clin Immunol Pract 7:1097-1106. https://doi.org/10.1016/j.jaip.2019.02.002

102. Theoharides TC, Tsilioni I, Ren H (2019) Recent advances in our understanding of mast cell activation-or should it be mast cell mediator disorders? Expert Rev Clin Immunol 15:639-656. https:// doi.org/10.1080/1744666X.2019.1596800

Translated by N. Goncharov 